\title{
Combination of Cyclophosphamide and Carboplatin in Recurrent Malignant Gliomas
}

\author{
Umut DEMIRCI ${ }^{1}$, Suleyman BUYUKBERBER ${ }^{2}$, Nuriye OZDEMIR ${ }^{3}$, Ugur COSKUN ${ }^{2}$, \\ Halit KARACA ${ }^{4}$, Muge AKMANSU ${ }^{5}$, Emel YAMAN 6 , Meltem BAYKARA ${ }^{2}$, \\ Deniz YAMAC ${ }^{2}$, Aytug UNER $^{2}$, Mustafa BENEKLI ${ }^{2}$
}

${ }^{1}$ Dr. Abdurrahman Yurtaslan Ankara Oncology Training and Research Hospital, Department of Medical Oncology, Ankara

${ }^{2}$ Gazi University Faculty of Medicine, Department of Medical Oncology, Ankara ${ }^{3}$ Numune Training and Research Hospital, Department of Medical Oncology, Ankara

${ }^{4}$ Erciyes University Faculty of Medicine, Department of Medical Oncology, Kayseri

${ }^{5}$ Gazi University Faculty of Medicine, Department of Radiation Oncology, Ankara

${ }^{6}$ Mersin State Hospital, Department of Medical Oncology, Mersin, TURKEY

\begin{abstract}
Eventually, all patients with malignant gliomas recur or progress. Unfortunately, the optimal regimen in the salvage setting has not yet been defined. We retrospectively evaluated 52 patients with malignant gliomas who failed temozolomide therapy and were treated with a combination of intravenous carboplatin and oral cyclophosphamide. The median age of all patients, including those with glioblastoma multiforme (GBM) $(n=40)$ and anaplastic glioma $(A G)(n=12)$, was 45.5 years (range 23-68). All patients were treated with consolidation temozolomide after chemoradiotherapy. After temozolomide failure, second surgery was performed on 15 , reirradiation on four and radiosurgery on three patients. The median number of chemotherapy cycles was 4 (range 1-8), the clinical benefit was $67.3 \%$, a partial response was achieved in $26.9 \%$ and stable disease in $40.4 \%$. In the GBM group, median progressionfree survival (PFS) and overall survival (OS) were $3(95 \% \mathrm{Cl}, 2.31-3.69)$ and 8 (95\% Cl, 4.76-11.24) months, respectively. In the AG group, median PFS and OS were $5(95 \% \mathrm{Cl}, 3.51-6.49)$ and $11(95 \% \mathrm{Cl}, 6.38-15.62)$ months, respectively. The six-month PFS rate was $25 \%$. Only one patient survived 18 months after treatment. Serious toxicity was mainly hematological.

The combination of carboplatin and oral cyclophosphamide is a valuable option in temozolomide refractory patients with malignant glioma.
\end{abstract}

Keywords: Malignant glioma, Recurrent, Cyclophosphamide, Carboplatin 


\section{Rekürren Malign Gliomlarda Siklofosfamid ve Karboplatin Kombinasyonu}

Malign glial tümörlü hastalar sonuçta progrese olur veya tekrarlar ve bu durumda optimal tedavi henüz tanımlanmamıştır. Temozolomid tedavi başarısızlığından sonra intravenöz karboplatin ve oral siklofosfamid kombinasyonu ile tedavi edilen malign gliomlu 52 hastayı retrospektif olarak değerlendirdik. Glioblastoma multiforme (GBM) $(n=40)$ ve anaplastik gliomlu $(A G)(n=12)$ tüm hastaların ortanca yaşları 45.5 (aralık, 23-68) idi. Tüm hastalar kemoradyoterapi sonrası konsolidasyon temozolomid ile tedavi edildiler. TemozoIomid başarısızığı sonrası, 15 hastaya ikinci cerrahi, dört hastaya ikincil radyoterapi ve üç hastaya da radyocerrahi uygulandı. Ortanca kemoterapi kürü 4 (aralık, 1-8) idi. Klinik fayda oranı \%67.3, kısmi yanıt \%26.9 ve stabil hastalık \%40.4 idi. GBM grubunda ortanca progresyonsuz sağkalım (PS) ve genel sağkalım (GS) sırası ile 3 ay (\%95 Cl, 2.31-3.69) ve 8 aydı (\%95 Cl, 4.76-11.24). AG grubunda ortanca PS ve GS sırası ile 5 ay (\%95 Cl, 3.51-6.49) ve 11 aydı (\%95 Cl, 6.38-15.62). Altı ay PS oranı \%25 idi. Sadece bir hasta tedavi sonrası 18 ay yaşadı. Ciddi toksisiteler esas olarak hematolojikti.

Karboplatin ve oral siklofosfamid kombinasyonu temozolomid refrakter malign glial tümörlü hastalarda dikkate değer seçenektir.

Anahtar Kelimeler: Malign gliom, Rekürren, Siklofosfamid, Karboplatin

\section{INTRODUCTION}

Glioblastoma multiforme (GBM) and anaplastic glial tumors (AG), known as malignant gliomas (MG), are the most common and aggressive types of primary brain tumors. ${ }^{1,2}$ The incidence rate of primary brain tumors has increased in the last 30 years. Maximal surgery and radiotherapy (RT) concurrent with temozolomide followed by adjuvant temozolomide is the standard of care for GBM, but is a less established therapy for AG ${ }^{3.5}$ Eventually, all patients with MG recur or progress. Unfortunately, the optimal regimen in the salvage setting has not yet been defined. After the first relapse, the average survival time for GBM and AG is 3 months and 6 months, respectively. Temozolomide, bevacizumab, nitrosourea, cyclophosphamide and platinum-containing regimens are used in salvage treatment. ${ }^{6}$ We have previously published results on the use of carboplatin and oral cyclophosphamide in the salvage treatment of MG.7 Here, we evaluated the efficacy and toxicity of the combination of intravenous carboplatin and oral cyclophosphamide in the salvage setting with longer follow-up and increased patient numbers.

\section{PATIENTS AND METHODS}

We retrospectively evaluated 52 patients with MG who failed temozolomide therapy, and were then treated with the combination of intravenous carboplatin and oral cyclophosphamide between May 2005 and August 2010. All patients had histopatho- logically proven MG based on the World Health Organization (WHO) classification. ${ }^{8}$ Patients with MG who had a progression or recurrence 6 months after RT and temozolomide were eligible for the study. All patients had measurable disease by contrast-enhanced magnetic resonance imaging (MRI). Spectroscopic MRI was performed to exclude radiation necrosis and pseudoprogression. Anti-epileptics and corticosteroids were used to control neurological signs and symptoms. Patients had adequate bone morrow, liver and renal functions.

Treatment consisted of intravenous carboplatin area under the curve (AUC) 6 (based on the Calvert formula) on day 1 and oral cyclophosphamide 75 $\mathrm{mg} / \mathrm{m}^{2}$ daily on days 1 to 14 , followed by 14 days of rest, with the treatment repeated every 4 weeks. Treatment response was evaluated after every 3 months by contrast-enhanced MRI and clinically according to the response criteria of the response assessment in neuro-oncology (RANO). ${ }^{9}$ Progression-free survival (PFS) and overall survival (OS) values were calculated from the date of relapse to progression and death, respectively. Toxicities were graded according to the National Cancer Institute Common Toxicity Criteria. ${ }^{10}$ Drug doses were reduced by $25 \%$ for subsequent cycles to avoid grade 3-4 hematological or reversible grade 3 non-hematological toxicities. Treatment was interrupted if any grade 4 non-hematologic toxicity occurred.

PFS and OS were estimated by the Kaplan-Meier method. Survival curves were compared with the log-rank test. P values less than 0.05 were accepted 


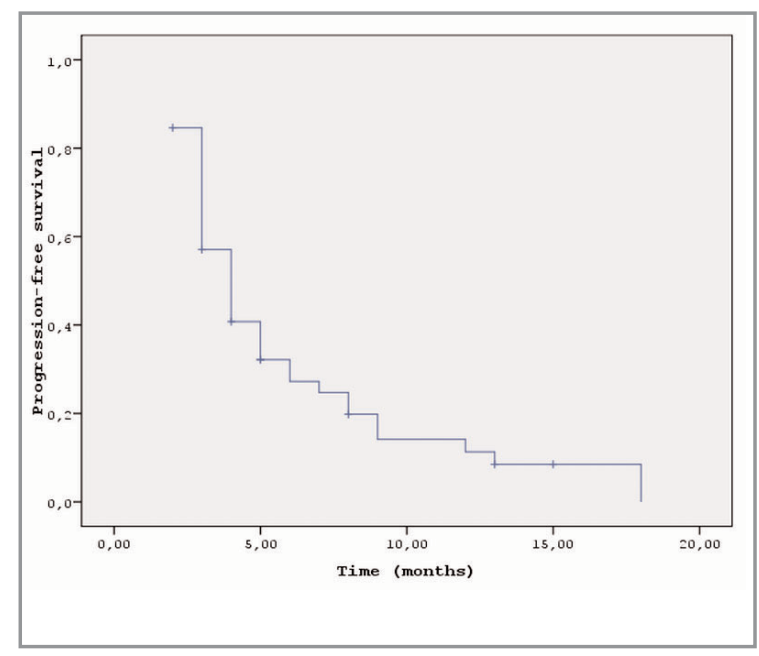

Figure 1. Kaplan Meier estimates of progression free survival by disease groups

\begin{tabular}{|ll|}
\hline \multicolumn{2}{|l|}{ Table 1. Patient Characteristics } \\
\hline Median age & $\mathbf{n}(\%)$ \\
Sex & 45.5 (range 23-68) \\
Male & $35(67.3 \%)$ \\
Female & $17(32.7 \%)$ \\
Grade of MG & \\
Grade IV & $40(76.9 \%)$ \\
Grade III & $12(23.1 \%)$ \\
Surgery & \\
Gross total resection & $34(65.4 \%)$ \\
Subtotal resection & $12(23.1 \%)$ \\
Stereotaxic biopsy & $6(11.5 \%)$ \\
Salvage treatment & \\
Surgery & $15(28.8 \%)$ \\
Reirradiation & $4(7.6 \%)$ \\
Radiosurgery & $3(5.7 \%)$ \\
\hline
\end{tabular}

as significant. The primary objectives of the study were to evaluate the efficacy and toxicity of the carboplatin and oral cyclophosphamide regimen as second-line therapy based on response to therapy, PFS, PFS at 6 months (PFS-6), OS and OS at 1 year.

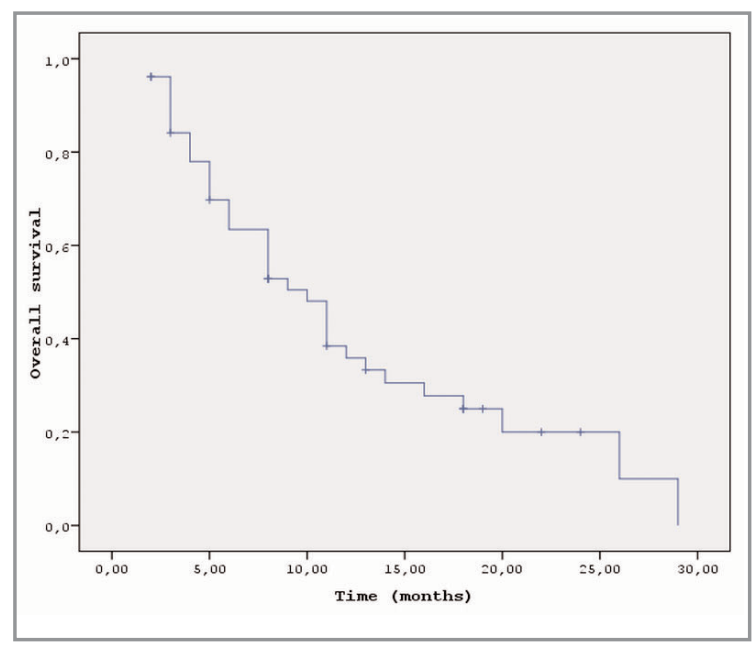

Figure 2. Kaplan Meier estimates of overall survival by disease groups

\section{RESULTS}

The patient characteristics are shown in Table 1. The AG were anaplastic astrocytoma $(n=9)$ and anaplastic oligodendrioglioma $(n=3)$. All patients were treated with consolidation temozolomide after RT plus concomitant temozolomide. The median number of temozolomide cycles was 6 (range 1-9). After temozolomide failure, second surgery was performed on $15(28.8 \%)$, reirradiation on four (7.6\%) and radiosurgery on three patients.

The median number of chemotherapy cycles was 4 (range 1-8) in a total of 52 patients with MG. Although there was no complete response, clinical benefit was $67.3 \%(n=35)$; a partial response (PR) was achieved in $26.9 \%(n=14)$ and stable disease in $40.4 \%(n=21)$. Median PFS and OS were 4 months (95\% CI; 3.17-4.84) and 10 (95\% CI; 7.812.62) months, respectively, in all study groups (Figure 1,2). In the GBM group, median PFS and OS were 3 (95\% CI, 2.31-3.69) and 8 (95\% CI, 4.76-11.24) months, respectively. In the AG group, median PFS and OS were 5 (95\% CI, 3.51-6.49) and 11 (95\% CI, 6.38-15.62) months, respectively. Pseudoprogression was detected in one patient, and radionecrosis in one patient. Six-month PFS and 1year OS rates were $25 \%$ and $9.6 \%$, respectively. Only one patient survived 18 months after treatment. The grade of MG ( $\mathrm{p}=0.331)$, total excision $(\mathrm{p}=0.335)$, recurrent surgery $(\mathrm{p}=0.441)$ and age $(<50$ and $>50$ years $)(p=0.344)$ did not show significant survival differences. 


\begin{tabular}{|ll|}
\hline Table 2. Severe toxicities & \\
\hline Grade Toxicities & $\mathbf{n}(\%)$ \\
\hline Hematologic (Grade) & \\
$\quad$ Thrombocytopenia & $9(17.3)$ \\
Anemia & $4(7.6)$ \\
Neutropenia & $12(23.0)$ \\
Febrile neutropenia & $5(2.9)$ \\
Nause and vomiting & $3(17.4)$ \\
Asthenia & $20(11.6)$ \\
Hepatic toxicity & $1(1.9)$ \\
\hline
\end{tabular}

While asthenia, nausea and vomiting were the most common toxicities, no toxic death occurred. Four patients discontinued treatment for hematotoxicity $(n=3)$ and poor performance status $(n=1)$. Serious toxicities (grade 3/4) were mainly hematological; thrombocytopenia $(n=9,17.3 \%)$, anemia $(n=4$; $7.6 \%)$ and neutropenia $(n=12 ; 23 \%)$; febrile neutropenia developed in three patients. Others serious adverse events were emesis $(n=5 ; 9.6 \%)$ and asthenia $(n=4 ; 7.5 \%)$. Acute hepatic failure developed in one patient because of hepatitis B activation (Table 2).

\section{DISCUSSION}

The majority of patients with MG have a poor prognosis after failing temozolomide therapy in the postoperative setting. Salvage therapies essentially offer palliative care as response rates have generally been less than $20 \%$ and PFS-6 is usually around 15$30 \%$. Commonly used drugs are temozolomide, bevacizumab, nitrosourea and irinotecan..$^{6,11,12}$ In a meta-analysis that included eight phase II trials, PFS6 was $31 \%$ and the response rate was $14 \%$ in patients with recurrent AG. PFS-6 was $25 \%$ and the objective response rate was $26.9 \%$ in this study. ${ }^{13}$ The response rates and survival time are similar to previous studies in recurrent $\mathrm{MG}$ patients.

Cyclophosphamide and carboplatin are alkylating agents; $50 \%$ clinical benefit has been shown with carboplatin as a single agent in patients with recurrent MG who had previously been treated with nit- rosourea. ${ }^{14-17}$ Similarly, the objective response rate of cyclophosphamide was $22.5 \%$, with $40 \%$ stable disease in temozolomide-refractory AG. PFS-6 was $30 \%$. Median PFS and OS were 4 months and 8 months, respectively ${ }^{18}$, when cyclophosphamide was evaluated in patients with GBM. Clinical benefit was $45.5 \%$ (PR 17.5\%), median time to progression (TTP) was 2 months, median OS was 4 months and PFS-6 was $20 \% .{ }^{19}$ The single agent toxicity of both carboplatin and cyclophosphamide are manageable, however when given together, their myelotoxic effects show synergism. In a previous study, their combination showed synergistic activity in the treatment of recurrent MG. A different schedule of this regimen was tested in MG with considerable residual disease. The study showed $20 \%$ clinical benefit (including 6.5\% PR), 7.6 months of median OS and $33 \%$ of 1 -year OS..$^{20}$ Although the response rates of grossly residual patients were inadequate in our previous study ${ }^{7}$, a combination of intravenous carboplatin and oral cyclophosphamide may be a effective regimen in patients with recurrent $\mathrm{MG}$, as the objective response rate was $30 \%$ and the median TTP and OS were 7 and 8 months, respectively. The present study included a greater number of patients $(n=52)$ with a longer follow-up period. Although there was no CR, the clinical benefit was $67.3 \%$, PR was $26.9 \%(n=14)$ and SD was $40.4 \%$ $(\mathrm{n}=21)$. In nearly 5 years of follow-up, PFS and OS were 4 and 10 months, respectively.

According to our institutional approach, patients with progressive MG should be considered for salvage therapy if their performance status is adequate. Treatment options are repeated surgery, radiosurgery, reirradiation or salvage chemotherapy. First, we evaluated patients in the case of progression for second surgery. A significant number of patients $(n=15,28.8 \%)$ underwent reoperation in whom pathological examination was confirmed as MG. Additionally, we performed reirradiation ( $\mathrm{n}=$ $4)$ and radiosurgery $(n=3)$. We did not give temozolomide, if the short-term response (less than 6 months) was achieved with temozolomide or progression developed with treatment. Known prognostic factors were age, grade of MG, type of surgery, O-6-methylguanine-DNA methyltransferase (MGMT) status of the tumor and performance sta- 
tus. ${ }^{20}$ However, we did not find a correlation between age, grade of MG, type of surgery and salvage surgery that could be explained due to the small number of AG patients $(n=12)$. While asthenia, nausea and vomiting were the most common toxicities, grade 3/4 toxicities were mainly hematological, such as thrombocytopenia and neutropenia. Slightly higher rates of toxicity were observed in a study by Vinolas et al..$^{21}$ This may have been related to the higher dose of carboplatin $\left(200 \mathrm{mg} / \mathrm{m}^{2}\right)$ used in that study.

Antiangiogenic therapy, i.e. bevacizumab combined with irinotecan, was approved in 2009 for the treatment of recurrent $\mathrm{MG}^{22,23} \mathrm{~A}$ challenging aspect of this therapy is the pharmacoeconomic impact, as both irinotecan and bevacizumab are extremely expensive chemotherapeutics. Additionally, for patients in whom bevacizumab therapy is contraindicated, the combination of cyclophosphamide and carboplatin may be an alternative regimen as it shows a negligible toxicity profile in patients with recurrent MG. However, one of the disadvantages of this study were the insufficient toxicity records due to the retrospective nature of the investigation.

We have demonstrated the efficiency of carboplatin and oral cyclophosphamide combination treatment in the long-term follow-up of temozolomide-refractory patients. This combination should be evaluated with different schemes in prospective studies.

\section{REFERENCES}

1. Jemal A, Bray F, Center MM, et al. Global cancer statistics. CA Cancer J Clin 61: 69-90, 2011.

2. http://www.cbtrus.org/ reports/2007-2008/2007report.pdf (Access date 6/5/2013).

3. Stupp R, Dietrich PY, Osterman Kraljevic S, et al. Promising survival for patients with newly diagnosed glioblastoma multiforme treated with concomitant radiation plus temozolomide followed by adjuvant temozolomide. J Clin Oncol 20: 1375-1382, 2002.

4. Athanassiou $\mathrm{H}$, Synodinou $M$, Maragoudakis $E$, et al. Randomized phase II study of temozolomide and radiotherapy compared with radiotherapy alone in newly diagnosed glioblastoma multiforme. J Clin Oncol 23: 2372-2377, 2005.

5. Stupp R, Hegi ME, Mason WP, et al. European Organisation for Research and Treatment of Cancer Brain
Tumour and Radiation Oncology Groups; National Cancer Institute of Canada Clinical Trials Group. Effects of radiotherapy with concomitant and adjuvant temozolomide versus radiotherapy alone on survival in glioblastoma in a randomised phase III study: 5-year analysis of the EORTC-NCIC trial. Lancet Oncol 10: 459-466, 2009.

6. Wen PY, Kesari S. Malignant gliomas in adults. N Engl J Med 359: 492-507, 2008.

7. Yaman E, Buyukberber S, Uner A, et al. Anatolian Society of Medical Oncology (ASMO). Carboplatin and oral cyclophosphamide combination after temozolomide failure in malignant gliomas. Tumori 94: 674-80, 2008.

8. Louis DN, Ohgaki H, Wiestler OD, et al. The 2007 WHO classification of tumours of the central nervous system. Acta Neuropathol. 114: 97-109, 2007.

9. Miller AB, Hoogstraten B, Staquet M, Winkler A. Reporting results of cancer treatment. Cancer. 47: 20714, 1981.

10. http://evs.nci.nih.gov/ftp1/CTCAE/CTCAE 4.03 201006-14 QuickReference 5x7.pdf (Access date, 6/1/2012)

11. Kyritsis AP, Levin VA. An algorithm for chemotherapy treatment of recurrent glioma patients after temozolomide failure in the general oncology setting. Cancer Chemother Pharmacol 67: 971-83, 2011.

12. Huncharek M, Muscat J. Treatment of recurrent high grade astrocytoma; results of a systematic review of 1,415 patients. Anticancer Res 18: 1303-11, 1998.

13. Wong ET, Hess KR, Gleason MJ, et al. Outcomes and prognostic factors in recurrent glioma patients enrolled onto phase II clinical trials. J Clin Oncol 17: 25722578, 1999.

14. Yung WK, Mechtler L, Gleason MJ. Intravenous carboplatin for recurrent malignant glioma: a phase II study. J Clin Oncol. 9: 860-864, 1991.

15. Warnick RE, Prados MD, Mack EE, et al. A phase ॥ study of intravenous carboplatin for the treatment of recurrent gliomas. J Neurooncol 19: 69-74, 1994.

16. Kaloshi G, Petrela M. Carboplatin Chemotherapy in Patients with Recurrent High-grade Glioma. Clin Oncol (R Coll Radiol) 23: 495, 2011.

17. Murray LJ, Bridgewater CH, Levy D. Carboplatin chemotherapy in patients with recurrent high-grade glioma. Clin Oncol (R Coll Radiol) 23: 55-61, 2011.

18. Chamberlain MC, Tsao-Wei DD, Groshen S. Salvage chemotherapy with cyclophosphamide for recurrent temozolomide-refractory anaplastic astrocytoma. Cancer 106: 172-179, 2006.

19. Chamberlain MC, Tsao-Wei DD. Salvage chemotherapy with cyclophosphamide for recurrent, temozolomide-refractory glioblastoma multiforme. Cancer 100: 1213-20, 2004. 
20. Curran WJ Jr, Scott CB, Horton J, et al. Recursive partitioning analysis of prognostic factors in three Radiation Therapy Oncology Group malignant glioma trials. J Natl Cancer Inst 85: 704-710, 1993.

21. Viñolas N, Gil M, Verger E, et al. Pre-irradiation semiintensive chemotherapy with carboplatin and cyclophosphamide in malignant glioma: a phase II study. Anticancer Drugs 13:163-167, 2002.

22. Vredenburgh JJ, Desjardins A, Herndon JE 2nd, et al. Bevacizumab plus irinotecan in recurrent glioblastoma multiforme. J Clin Oncol 25: 4722-4729, 2007.

23. Friedman HS, Prados MD, Wen PY, et al. Bevacizum$\mathrm{ab}$ alone and in combination with irinotecan in recurrent glioblastoma. J Clin Oncol 27: 4733-4740, 2009.

\section{Correspondence}

Dr. Umut DEMIRCi

Dr. Abdurrahman Yurtaslan Ankara Onkoloji

Eğitim ve Araştırma Hastanesi

Tıbbi Onkoloji Bölümü

Demetevler, ANKARA / TURKEY

Tel: (+90.312) 3360909

Fax: (+90.312) 3369681

e-mail: drumutdemirci@gmail.com 